\title{
Corrosion of Steel in High-Strength Self-Compacting Concrete Exposed to Saline Environment
}

\author{
Hana A. Yousif, ${ }^{1,2}$ Farqad F. Al-Hadeethi, ${ }^{3}$ Bashar Al-Nabilsy, ${ }^{4}$ and Amani N. Abdelhadi ${ }^{3}$ \\ ${ }^{1}$ Building and Construction Engineering Department, University of Technology, Alsinaa Street, 12906 Baghdad, Iraq \\ ${ }^{2}$ Building Research Center, Royal Scientific Society (RSS), Al-Jubaiha, Amman 11941, Jordan \\ ${ }^{3}$ Scientific Research Center, Applied Science Sector, Royal Scientific Society, Al-Jubaiha, Amman 11941, Jordan \\ ${ }^{4}$ Conformity and Quality Institutional Company, Abdul Hameed Badees Street 45, Shmeisani, Amman 11121, Jordan
}

Correspondence should be addressed to Hana A. Yousif; hanaatech@yahoo.com

Received 9 January 2014; Accepted 6 April 2014; Published 23 April 2014

Academic Editor: Flavio Deflorian

Copyright (c) 2014 Hana A. Yousif et al. This is an open access article distributed under the Creative Commons Attribution License, which permits unrestricted use, distribution, and reproduction in any medium, provided the original work is properly cited.

\begin{abstract}
A research work was carried out to investigate the effectiveness of high-strength self-compacting concrete (SF-R) in controlling corrosion of embedded steel. Reinforced concrete cylinders and plain cubes were subjected to $5 \% \mathrm{NaCl}$ solution. Slump flow, J-ring, V-funnel, compressive strength, electrical resistance, and electrochemical tests were conducted. Corrosion resisting characteristics of steel were examined by monitoring corrosion potential, polarization resistance, corrosion currents, and Tafel plots. The relationship between corrosion current density and corrosion potential was established. Results were compared with characteristics of a grade $40 \mathrm{MPa}$ reference concrete (R) and grade $70 \mathrm{MPa}$ conventional self-compacting concrete (SP). Results indicated that at 270 days of exposure, the corrosion currents for steel in SF-R were 63- and 16-fold lower compared to those of steel in R and SP concretes, respectively. This concrete showed a considerable increase in electrical resistance and compressive strength of $96 \mathrm{MPa}$ at 28 days of exposure. Relying on corrosion risk classification based on corrosion current densities and corrosion potentials, the steel in SF-R concrete is definitely in the passive condition. The splendid durability performance of steel in SF-R concrete linked to adorable self-compacting features could furnish numerous opportunities for future structural applications in severe environmental conditions.
\end{abstract}

\section{Introduction}

Corrosion of reinforcing steel in concrete and the high repair and rehabilitation costs of structures associated with materials failures are nowadays a matter of considerable concern and forcing the engineers to become durability conscious. An increasing number of incidents of structural problems arising from corrosion of steel associated with chloride intrusion have been reported from different parts of the world $[1,2]$. The damage to concrete resulting from corrosion of steel may lead to a reduction in service life or precocious structural damage due to loss of bond between steel and concrete and reduction of steel cross-sectional area [3]. Therefore, construction engineer should focus on producing dense, high-quality concrete with very low permeability which consequently limits the intrusion of the corrosion inducing substances. Building elements made of high-strength concrete are usually densely reinforced. The small distance between reinforcing bars may lead to defects in concrete. Therefore, suitable compaction is necessary to ensure that adequate strength and durability are achieved. Insufficient compaction will lead to the inclusion of voids, which not only lead to a reduction in strength but also strongly influence the natural physical and chemical protection of embedded steel reinforcement afforded by concrete. Accordingly, the utilization of high-strength selfcompacting concrete in structural elements exposed to saline environment may provide splendid performance in terms of self-compacting features without any external means of consolidation [4]. Furthermore, the wonderful flowability, filling ability, and high resistance to segregation of SCC lead to consistent and dense microstructure characterized by the low porosity of the matrix and interfacial transition zone and consequently enhance the electrical resistance and limit the transmission properties of concrete. These features may promote the durability characteristics and conserve the reinforcing steel versus corrosion [5]. The low capillary 
TABLE 1: Chemical composition of cement and SF.

\begin{tabular}{|c|c|c|c|c|c|c|c|c|c|c|c|c|c|c|}
\hline Components & $\mathrm{CaO}$ & $\mathrm{SiO}_{2}$ & $\mathrm{Al}_{2} \mathrm{O}_{3}$ & $\mathrm{Fe}_{2} \mathrm{O}_{3}$ & $\mathrm{SO}_{3}$ & $\mathrm{MgO}$ & $\mathrm{K}_{2} \mathrm{O}$ & $\mathrm{Na}_{2} \mathrm{O}$ & LOI & IR & $\mathrm{C}_{3} \mathrm{~S}$ & $\mathrm{C}_{2} \mathrm{~S}$ & $\mathrm{C}_{3} \mathrm{~A}$ & $\mathrm{C}_{4} \mathrm{AF}$ \\
\hline $\mathrm{C}$ & 63.3 & 20.8 & 5.0 & 3.2 & 2.8 & 2.8 & 0.6 & - & 0.9 & 0.8 & 53.3 & 19.7 & 7.9 & 9.8 \\
\hline SF & - & $>90$ & - & - & - & - & - & - & $<3$ & - & - & - & - & - \\
\hline
\end{tabular}

porosity and high electrical resistance limit the chloride penetration and impede the electrochemical reaction and therefore prevent corrosion of steel reinforcement.

Numerous researchers have been investigating various corrosion resistance characteristics and related durability features of SCC and confirmed to be superior to normal concrete (NC). Their investigations involved essentially the permeation properties [6], steel-concrete interface defects [7], chloride penetration $[8,9]$, oxygen permeability and accelerated carbonation [8], electrical resistivity, porosity, and transport properties [10], structural performance under four-point loading after exposing to corrosive environment [11], chloride permeability [12, 13], diffusion coefficient [13], reinforcement corrosion initiation and chloride ion content $[14,15]$, and corrosion loss of steel $[10,14]$. Despite vital importance and extensive application of SCC in chloride laden environments, extremely little research work [7, 12] has been published about some electrochemical behaviors of steel in self-compacting concrete exposed to the severe saline environment.

The main objective of the current research work is to investigate the electrochemical corrosion performance of reinforcing steel in high-strength self-compacted concrete. The concrete incorporated high performance super plasticizer and silica fume as a partial replacement by weight of cement as well as an addition to cement. The electrochemical corrosion resisting characteristics of steel were examined by monitoring half-cell potentials, linear polarization resistance, corrosion currents, and Tafel plots. The strength of the SCC and the DC electrical resistance of the corrosion carrying media were also examined. The results of this study provide a vital reference for future structural application and design, particularly for structures exposed to deicing salts and those located in a coastal marine environment.

\section{Research Significance}

Intensive research studies were required to examine corrosion resisting characteristics of steel in SCC. The performance of reinforced SCC in aggressive environment may diverge widely depending on the mix formulation. Therefore, investigations addressing the influence of the various types of powders, their specific surface area, and mix design on the flowability, resistance to segregation, permeability, and durability of steel in the SCC are needed to manage the electrochemical reactions and meet the design life under certain environmental conditions.

The utilization of high-strength self-compacting concrete (HS-SCC) has increased vastly worldwide, and their applications were expanded to structural members situated in severe environmental conditions. However, the electrochemical corrosion which was extremely important concern has
TABle 2: Proportion of concrete mixes.

\begin{tabular}{|c|c|c|c|c|c|c|}
\hline \multirow{2}{*}{ Symbol } & \multicolumn{4}{|c|}{ Mix ingredients, $\mathrm{kg} / \mathrm{m}^{3}$} & \multirow{2}{*}{$\mathrm{w} / \mathrm{c}$ or $\mathrm{w} / \mathrm{cm}$} & \multirow{2}{*}{ SP $\%$} \\
\hline & $\mathrm{C}$ & SF & FA & CA & & \\
\hline $\mathrm{R}$ & 550 & - & 780 & 850 & 0.52 & - \\
\hline SP & 550 & - & 780 & 850 & 0.31 & 3 \\
\hline SF-R & 495 & 55 & 780 & 850 & 0.31 & 3 \\
\hline SF-A & 550 & 55 & 780 & 850 & 0.31 & 3 \\
\hline
\end{tabular}

not been investigated yet and was very limited for steel in SCC. Moreover, well controlled HS-SCC may produce a high durability system, provide lower electronic conduction and high electrical resistance that hinders the flow of the corrosion currents, maintain high $\mathrm{pH}$ level in the vicinity of steel, improve corrosion resisting characteristics, and extend the service life of the structure.

\section{Experimental Details}

3.1. Materials and Mix Proportions. The cement used in this study was ordinary Portland cement (OPC) that conforms to ASTM C 150 [16] Type I. Elkem Microsilica Grade 940 D with a typical bulk density of $500-700 \mathrm{~kg} / \mathrm{m}^{3}$ conforming to ASTM C 1240 [17] was used as a highly active mineral admixture for the production of HS-SCC. Silica fume (SF) contained greater than $90 \% \mathrm{SiO}_{2}$ and less than $3 \%$ carbon. The chemical composition of cement (C) and SF according to the producer is shown in Table 1. "Flocrete PC260" from Don Construction Products (DCP) Ltd. based on polycarboxylic ether polymer was used as a high-performance superplasticizer (SP) for reducing water content of the mix. It meets the requirements of ASTM C 494 Type A and F [18]. A mixture of 40\% Swelh sand and $60 \%$ Sel sand and crushed coarse aggregate with particle sizes 12.5 to $4.75 \mathrm{~mm}$ conforming to ASTM C 33 [19] were used. Table 2 lists the details of the mix proportions. Steel reinforcement with an effective diameter of $15.8 \mathrm{~mm}$ was calculated based on unit weight of steel, and the weight of the rebar of $305 \mathrm{~mm}$ in length was used.

Four types of concrete mixes were used; reference concrete mix (R) was designed to have 28 days characteristic compressive strength of $40 \mathrm{MPa}$ with a slump of $180 \mathrm{~mm}$, and conventional self-compacting concrete (SP) incorporating only 3\% SP was designed to yield 28 days strength of $70 \mathrm{MPa}$. Further, two HS-SCC were used: SF-R and SF-A concretes incorporating $3 \% \mathrm{SP}$ and $10 \% \mathrm{SF}$ as a partial replacement by weight of cement for the former and as an addition to the latter. There is no standard method for the design of SCC mixes. Mix design often uses volumes as key parameters because of the importance of the need to overfill the voids between the aggregate particles [20]. The details of the mixes are presented in Table 2. 
TABLE 3: Self-compacting features.

\begin{tabular}{|c|c|c|c|c|}
\hline \multirow{2}{*}{ Symbol } & \multirow{2}{*}{ SP \% } & \multirow{2}{*}{$\mathrm{w} / \mathrm{c}$ or $\mathrm{w} / \mathrm{cm}$} & \multicolumn{2}{|c|}{ Self-compacting features } \\
\hline & & & Tests & Actual value \\
\hline $\mathrm{R}$ & - & 0.52 & Slump & $180 \mathrm{~mm}$ \\
\hline SP & 3 & 0.31 & $\begin{array}{c}\text { Slump flow } \\
T 50 \mathrm{~cm} \\
\text { J-ring flow Passing } \\
\text { ability } \\
\text { V-funnel time }\end{array}$ & $\begin{array}{l}710 \mathrm{~mm} \\
7 \mathrm{sec} \\
700 \mathrm{~mm} \\
13 \mathrm{~mm} \\
8 \mathrm{sec}\end{array}$ \\
\hline SF-R & 3 & 0.31 & $\begin{array}{c}\text { Slump flow } \\
T 50 \mathrm{~cm} \\
\text { J-Ring flow } \\
\text { Passing ability } \\
\text { V-funnel time }\end{array}$ & $\begin{array}{c}683 \mathrm{~mm} \\
7 \mathrm{sec} \\
670 \mathrm{~mm} \\
13 \mathrm{~mm} \\
9 \mathrm{sec} \\
\end{array}$ \\
\hline SF-A & 3 & 0.31 & $\begin{array}{c}\text { Slump flow } \\
T 50 \mathrm{~cm} \\
\text { J-Ring flow } \\
\text { Passing ability } \\
\text { V-funnel time }\end{array}$ & $\begin{array}{c}675 \mathrm{~mm} \\
8 \mathrm{sec} \\
660 \mathrm{~mm} \\
15 \mathrm{~mm} \\
9 \mathrm{sec}\end{array}$ \\
\hline
\end{tabular}

3.2. Trial Mixes and Self-Compacting Tests. Self-compacting concrete must have the ability to flow under its own weight, to pass easily between reinforcing bars or other obstacles without segregation during or after casting. Trial mixes were conducted to address these fresh properties and to monitor $\mathrm{w} / \mathrm{c}$ or $\mathrm{w} / \mathrm{cm}$ materials ratio and superplasticizer dosage. Concretes were mixed using pan mixer. Slump test in accordance with ASTM C 143 [21] was used to determine the workability of R mix. Slump flow based on ASTM C 1611 [22], J-ring according to ASTM C1621 [23], and Vfunnel tests based on EFNARC [24] were carried out to examine the self-compacting features of SCC mixes. The slump flow test is used to examine the horizontal free flow of self-compacted concrete in the absence of obstructions. The diameter of the concrete circle is a measure of filling ability. The flow rate is influenced by the concrete's viscosity, and the stability can be observed by visually examining the concrete patty for evidence of segregation. The J-ring test is used to determine the passing ability in combination with the slump flow test. The J-ring is placed outside the slump cone so that the concrete flows through the legs of the ring when the cone is lifted. The slump flow with and without the J-ring is measured. A difference of less than $25 \mathrm{~mm}$ indicates a good passing ability. The V-funnel test is used to measure the ease of flow and filling ability of concrete. The funnel is filled with concrete and the time taken for it to flow through the apparatus is measured. Shorter flow time indicates greater flowability. Target values are slump flow of 550-750 $\mathrm{mm}$ and $\mathrm{V}$-funnel time of 6 to 12 seconds. The self-compacting features are demonstrated in Table 3.

3.3. Specimens Preparation and Exposure Condition. Four cylindrical series were prepared for electrochemical corrosion measurements. Specimens were $100 \mathrm{~mm}$ in diameter and $200 \mathrm{~mm}$ in length, reinforced with deformed mild steel rebar of $16 \mathrm{~mm}$ in diameter. The rebar has an effective cover of $42 \mathrm{~mm}$ and was protruding from the upper surface of the cylinder. The rust on the rebar was cleaned by steel brush and $\mathrm{SiC}$ sand paper. The specimens for electrical resistance and compressive strength measurements were $100 \mathrm{~mm}$ cubes cast also in four series. Concrete poured into the molds in three layers for cylindrical specimens and in two layers for cubes, and compaction was applied using vibrating table for $\mathrm{R}$ mixes, while SP and HS-SCC mixes neither needed any vibration nor surface leveling. After casting, specimens were covered with nylon sheets for 24 hours to prevent evaporation and then removed from the molds and cured for 27 days in a controlled environment of $25 \pm 2^{\circ} \mathrm{C}$ temperature and about 95\% relative humidity. During this period, the projected portions of the rebar were wrapped with sealed tape to prevent corrosion. At the end of the curing period, specimens were placed in laboratory air for three days then partially immersed in a $5 \% \mathrm{NaCl}$ solution in vertical position to accelerate the deterioration process. The level of the solution was adjusted so that half the depth of the specimens was in solution continuously. Measurements were conducted at ages of 7, 60, 90, 120, 150, 180, and 270 days of exposure to $5 \% \mathrm{NaCl}$ solution. The compressive strength tests for the four series were carried out in accordance with ASTM C39 [25] using a digitally controlled compression machine with a maximum load capacity of $2000 \mathrm{KN}$. For each measurement, a set of six specimens was used for HS-SCC and a set of three specimens for $\mathrm{R}$ and SP specimens.

3.4. Half-Cell Potential (HCP) Measurements. The half-cell potential has been greatly used in the laboratory and in the field for the assessment of the corrosion potential of steel reinforcement in concrete. It is nonintrusive test and provides a rapid and inexpensive means of identifying zones of active corrosion in reinforced concrete structures that need further analysis and rehabilitation [3]. The test was performed based on ASTM C876 [26] to determine the corrosion activity and the time to corrosion initiation. The principal concerned with this technique is basically a measurement of corrosion 


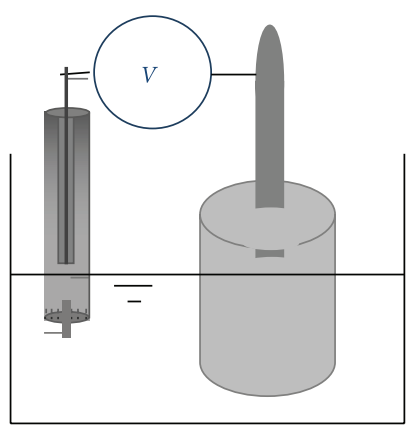

FIGURE 1: Half-cell potential setup.

potential of the working electrode (steel reinforcement in concrete) as the voltage difference between the steel and a standard reference electrode close to concrete surface [2729]. Silver/silver chloride $(\mathrm{Ag} / \mathrm{AgCl})$ was used as a standard reference electrode, Figure 1. Electrically, the reinforcing steel has to be connected to the positive terminal of the voltmeter and the half-cell to the negative (ground) terminal of the voltmeter. Precaution measures were taken to maintain the half-cell in proper conditions during the testing period. Halfcell potential measurements were taken at scheduled periods. The potentials recorded in the half cell readings can be used to indicate the probability of reinforcement corrosion. If the potentials are less negative than $-0.119 \mathrm{~V} \mathrm{Ag} / \mathrm{AgCl}$, there is greater than $90 \%$ probability that no reinforcing steel corrosion was occurring at the time of measurement. If the potentials are in the range of -0.119 to $-0.269 \mathrm{~V} \mathrm{Ag} / \mathrm{AgCl}$ corrosion activities are uncertain. If the potentials are more negative than $-0.269 \mathrm{~V} \mathrm{Ag} / \mathrm{AgCl}$ there is greater than $90 \%$ risk of corrosion [26].

3.5. Corrosion Current Measurements. Corrosion currents were determined by Tafel extrapolation methods. Three electrodes were used: reinforcing steel as a working electrode, $\mathrm{Ag} / \mathrm{AgCl}$ electrode as standard reference electrode and copper plate measuring $60 \times 30 \times 3 \mathrm{~mm}$ as the auxiliary electrode. The electrical connection of the reinforcement was secured by pin connected to the projected part of the bar. The experimental setup is shown in Figure 2. Measurements were carried out to determine the polarization resistance $\left(R_{p}\right)$ using small potential scan within $\pm 20 \mathrm{mV}$ from Ecorr at the scan rate of $0.167 \mathrm{mV} / \mathrm{s}$. The amount of polarization shift $(\Delta E)$ was selected within linear Stern-Geary range of $10-30 \mathrm{mV}$ [30] to avoid electrochemical disturbance of the polarized electrode during the test. In the present work, $R_{p}$ was obtained directly using the " $R_{p}$ fit graphic tool" associated with Software techniques. The fundamentals of this technique are based on the following Stern-Geary equation [30]:

$$
R_{p}=\frac{\Delta E}{\Delta I}
$$

Tafel extrapolation is used to determine the polarization curve. The anodic and cathodic Tafel constants $\beta a$ and $\beta c$ were determined from Tafel plots. The Tafel slopes $\beta a$ and $\beta c$ are the voltage change per one logarithmic cycle of

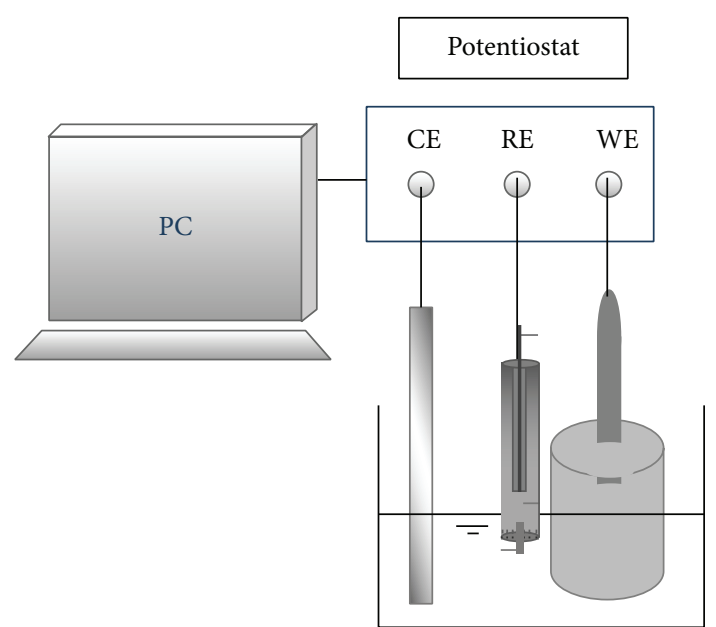

FIgURE 2: Corrosion current measurement setup.

current (volts per decade) in the positive (Nobel) and negative (Active) direction, respectively. The back extrapolation lines intersect at a point on line of corrosion potential, Ecorr, and the projection of this point on the current scale gives the value of the Icorr. In the present work, the potentiostat instrument and general-purpose electrochemical system (GPES) software package were used to plot polarization curves and determine corrosion rates, $\beta a$ and $\beta c$ with Tafel fits. This technique is designed for plotting polarization curves and determining Icorr through potential steps of $\pm 100 \mathrm{mV}$ around the corrosion potential. Work has been done in correlating $i$ corr to the condition of the rebar [27]; where $i$ corr $<0.1 \mu \mathrm{A} / \mathrm{cm}^{2}$, steel is in a passive condition, icorr 0.1 to $0.5 \mu \mathrm{A} / \mathrm{cm}^{2}$ corrosion risk is low to moderate, icorr 0.5 to $1 \mu \mathrm{A} / \mathrm{cm}^{2}$ corrosion risk is moderate to high, and icorr $>1 \mu \mathrm{A} / \mathrm{cm}^{2}$ corrosion risk is high. The surface area $(A)$ of the steel reinforcement that has been polarized needs to be accurately known for determination of the corrosion current density (icorr) as in the following equation:

$$
i \text { corr }=\frac{I \text { corr }}{A} .
$$

The corrosion rate (CR) in a millimeter per year (mmpy) is calculated according to the next equation:

$$
\mathrm{CR}=\frac{I \operatorname{corr} \cdot K \cdot \mathrm{EW}}{d \cdot A},
$$

Icorr is corrosion current,

$K$ is constant that defines the units of the corrosion rate $(3272 \mathrm{~mm} /(\mathrm{A} \cdot \mathrm{cm} \cdot$ year $)$,

EW is equivalent weight of steel (atomic weight/valence of the reacting electrode (iron) $27.9225 \mathrm{~g} / \mathrm{eq}$ ),

$d$ is density, $7.8 \mathrm{~g} / \mathrm{cm}^{3}$,

$A$ is sample surface area, $78.4 \mathrm{~cm}^{2}$. 


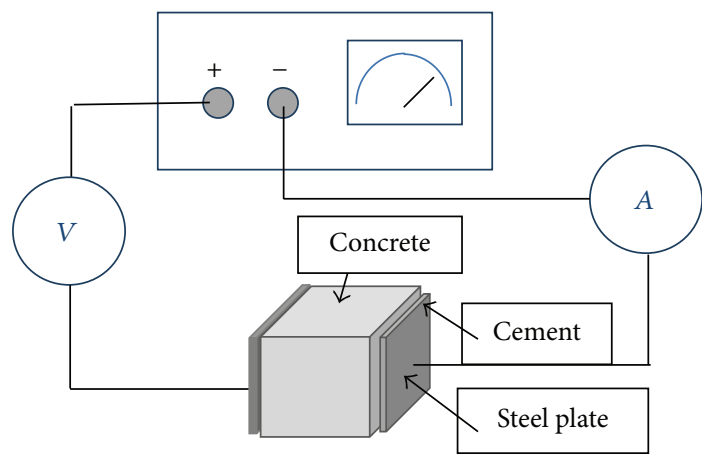

FIGURE 3: Electrical resistance measuring setup.

3.6. Electrical Resistance Measurements. Direct electric current (DC) technique was exercised for electrical resistance measurements of the concrete cubes. A constant electric field was applied between two external electrodes, and the resulting current was measured. The electrical resistance measuring setup includes DC power supply, two high performance digital multi-meters, used as voltage and current measuring devices and two stainless steel plates, measuring $100 \times 100 \times 3 \mathrm{~mm}$ were used as external electrodes. Steel plates were cleaned thoroughly using $\mathrm{SiC}$ paper to ensure good conductivity. The two plates were lasted to the opposite sides of the specimen using cement paste with a w/c or w/cm materials ratio analogous to those of the test specimen to avoid a significant change in resistance due to the polarization effect. The electrical circuit for DC resistance measurement is shown in Figure 3. The specimens were investigated over a wide range of output voltages. At each selected voltage, the synchronous value of current was recorded. The electrical resistance of concrete specimens was determined by the slope of the voltage-current plot. The average of three specimens, measured just after removal from the solution was adopted at the scheduled ages. This ensured continuous electrical connectivity across the gap separating the electrodes. The resistance of concrete was determined by the slope of the line of the voltage current plots. The resistivity then is calculated from the following equation:

$$
\rho=A \cdot \frac{R}{L}
$$

\section{$R:$ resistance $(\mathrm{Ohm})$ \\ $\rho$ : resistivity $(\mathrm{Ohm} \cdot \mathrm{cm})$}

$A$ : cross-sectional area the current flows through $=$ $10 \times 10=100 \mathrm{~cm}^{2}$

$L$ : the gap separating the electrodes.

\section{Results and Discussions}

4.1. Half-Cell Potential (HCP). The HCP data presented in Figure 4 indicated that at the end of 28 days curing in tap water the steel potentials in concretes were in the range of $-124 \mathrm{mV}$ to $-360 \mathrm{mV} \mathrm{Ag} / \mathrm{AgCl}$. According to Arup [31] in

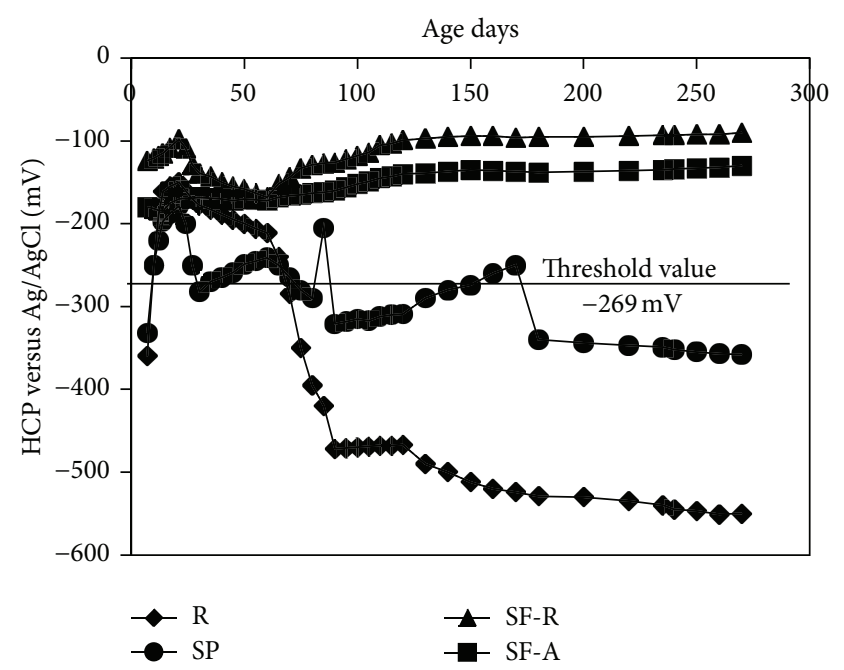

FIGURE 4: Half-cell potentials (HSPs) with age.

the absence of chlorides, the reinforcing steel in concrete is in the passive state brought about by the high $\mathrm{pH}$ and the availability of oxygen. The range of passive potential, however, is very wide from $+200 \mathrm{mV}$ to $-700 \mathrm{mV}$ CSE or more negative against $\mathrm{Ag} / \mathrm{AgCl}$ at $\mathrm{pH} 13$. Consequently, in this state, the potentials more negative than ASTM C-876 threshold value $(-269 \mathrm{mV} \mathrm{Ag} / \mathrm{AgCl})$ do not indicate, with any degree of accuracy that corrosion of steel reinforcement is occurring at the end of 28 days curing. At an early stage of immersion in $5 \% \mathrm{NaCl}$ solution the reinforcing steel potentials, in general, rapidly changed to values less negative than the initial potentials. This is clearly indicative of a change in the electrochemical status due to the presence of chloride ions in the solution. Thereafter, the reinforcing steel in SF-R and SF-A concretes exhibited gradual variation in potentials toward more negative values up to 60 days of exposure and then varied continuously toward less negative potentials up to the end of the testing period, Figure 4. In those specimens, a threshold value of $-269 \mathrm{mV} \mathrm{Ag} / \mathrm{AgCl}$ was not exceeded and corrosion activity of reinforcing steel is uncertain based on ASTM C876 [26]. Furthermore, the steel in $\mathrm{R}$ and SP concretes showed rapid and great variations toward more negative potentials and a threshold value of $-269 \mathrm{mV} \mathrm{Ag} / \mathrm{AgCl}$ based on ASTM C876 was exceeded after 70 days of exposure. This is indicating corrosion initiation according to ASTM C876 in R and SP specimens at 70 days of exposure, Figure 4, due to penetration of chloride ions and breakdown of the passive protective layer.

The measurements are too susceptible to the humidity standing on the concrete, oxygen availability in the proximity of the steel and micro cracks in concrete. More negative potentials result for steel in concrete with a higher degree of saturation, lack of oxygen in the vicinity of the reinforcement and the presence of localized micro cracks [3]. The superior performance of steel in a system of lower corrosion activity, SF-R and SF-A specimens, may be explained in terms of pores size and continuity, hence, the penetrability of the solution aggressive species. Therefore, these systems 
TABLE 4: Polarization resistance and proportionality constant.

\begin{tabular}{|c|c|c|c|c|c|c|c|c|}
\hline \multirow{2}{*}{ Age $-\mathrm{d}$} & \multicolumn{4}{|c|}{$R_{p}-\mathrm{Ohm}$} & \multicolumn{4}{|c|}{$\beta-\mathrm{mV} /$ decade } \\
\hline & $\mathrm{R}$ & SP & SF-R & SF-A & $\mathrm{R}$ & SP & SF-R & SF-A \\
\hline 7 & 139 & 237 & 1973 & 1700 & 31 & 36 & 82 & 62 \\
\hline 60 & 211 & 312 & 2715 & 2523 & 66 & 58 & 77 & 70 \\
\hline 120 & 232 & 381 & 2900 & 2100 & 68 & 56 & 68 & 58 \\
\hline 150 & 265 & 481 & 3064 & 2023 & 73 & 55 & 62 & 46 \\
\hline 180 & 623 & 745 & 6167 & 5989 & 112 & 98 & 77 & 120 \\
\hline 270 & 1074 & 1268 & 9592 & 8095 & 150 & 119 & 90 & 154 \\
\hline
\end{tabular}

have a higher electrical resistance and superior internal integrity, thus, reducing the likelihood for the intrusion of aggressive chloride ions, that is, the factors that manage the electrochemical corrosion activity. Attempts, however, to describe the electrochemical process in terms of potential measurements is irritating and not adequate as a criterion. Accordingly, may result in improper conclusions, since they are affected by many factors such as polarization caused by limited propagation of oxygen [26-28], the existence of highly resistive layers and concrete porosity [32]. Further, deceptive conclusions regarding corrosion risk may result in a structure where portions are exposed to dry conditions while others remain moist [3]. Thus, potentials readings should be interpreted together with corrosion rate data as considered in this work.

4.2. Corrosion Current. Polarization resistance and Tafel extrapolation techniques were applied to all series. Three specimens were tested at each scheduled age. Examination of the Tafel data indicated that the corrosion process of steel reinforcement embedded in all types of concrete is cathodically controlled, since the cathodic Tafel slope $(\beta c)$ is greater than the anodic slope $(\beta a)$. This means that corrosion is determined by polarization of the cathodic controlling reactions, that is, the electrode is accelerated by moving the potential in the negative (active) direction. Figure 5 represents typical Tafel plots at 7 days of exposure to $\mathrm{NaCl}$ solution. The proportionality constants $(\beta)$, were in the range of $31-150 \mathrm{mV} /$ decade for steel in $\mathrm{R}$ concrete, $36-119 \mathrm{mV} /$ decade in SP concrete, $62-90 \mathrm{mV} /$ decade in SF$\mathrm{R}$ concrete and $46-154 \mathrm{mV} /$ decade in SF-A concrete. The average $R_{p}$ and proportionality constant determined from Tafel plots (TP) at scheduled ages are shown in Table 4 and the variation of the corrosion current with exposure time is shown in Figure 6. Results reveal that, in general the corrosion current of steel in SF-R concrete exhibited a gradual reduction with exposure time, while in SF-A concrete showed a slight increase in the corrosion current as compared to steel in SF-R concrete after 150 days of exposure. On the other hand, the steel in $\mathrm{R}$ concrete showed a rapid increase in corrosion current and in SP concrete exhibited, a gradual increase after 60 days indicating a breakdown in the passive film as a result of chloride ion ingress. However, the increase in the corrosion current is more pronounced for steel in $\mathrm{R}$ concrete compared to steel in SP concrete.

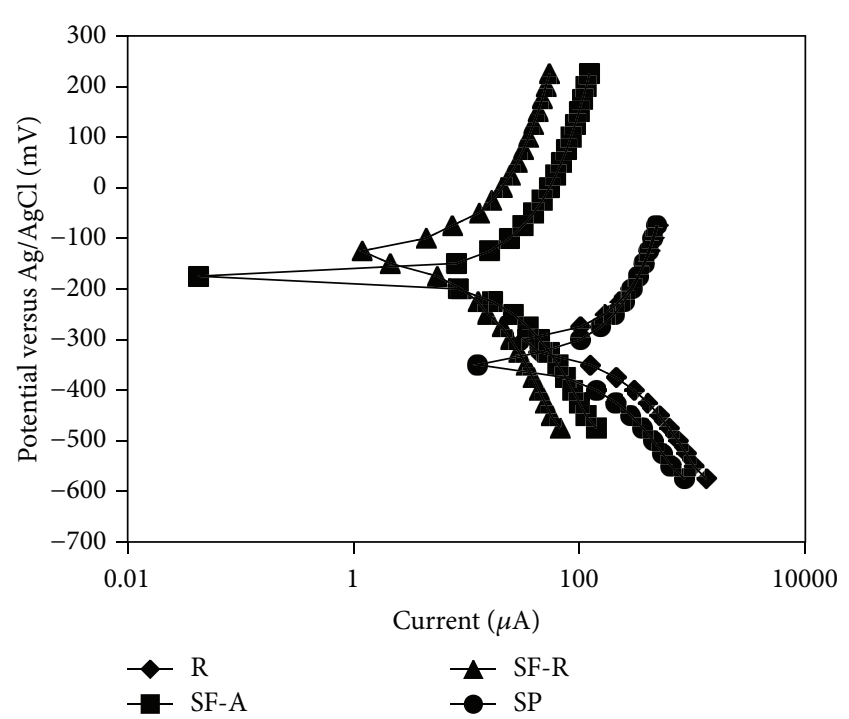

FIGURE 5: Polarization curves at 7 days of exposure.

Examination of the Tafel plots and data in Figure 6 for steel in SF-R concrete indicated that at the end of the testing period the corrosion currents are 63 and 16 fold lower than those for steel in R, and SP concretes respectively. The corresponding values for steel in SF-A concrete are 17 and 4 fold lower. Superior corrosion resistance performance of steel in SF-R concrete over the R as well as SP concrete is attributed to many reasons: The utilization of high surface area silica fume leads to progressive improvement in the internal microstructural system and the transition zone through the pore size and grain size refinement processes, hence blocking the continuity of the voids [3]. The use of high performance super plasticizer produced concrete mix of excellent flowability and high resistance to segregation, with a $40 \%$ water reduction. The well dispersion of the cementitious particles by the action of superplasticizer produces a homogeneous and dense microstructure. Furthermore, the tight microstructure can impede the movement of electrons from the anode to the cathode zone, thus, tends to hinder the propagation of the corrosion process. These features as a parcel contribute positively to reduce corrosion current of SF-R. Based on corrosion current density's data presented in Table 5 and according to Rodriguez et al. [27] corrosion risk 


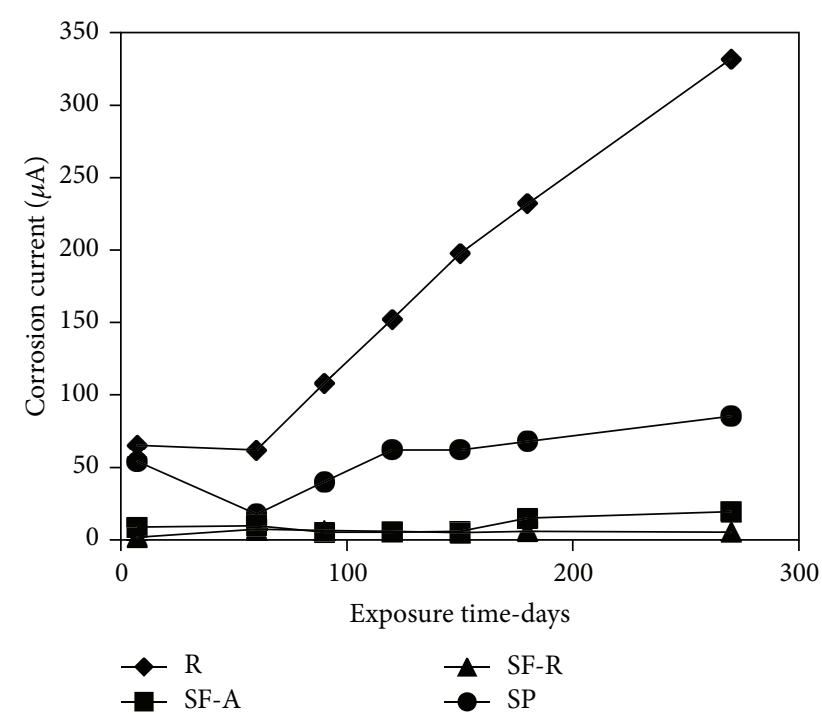

Figure 6: Corrosion currents versus time of exposure.

TABLE 5: Corrosion current density.

\begin{tabular}{lcccc}
\hline \multirow{2}{*}{ Age-d } & \multicolumn{4}{c}{ Corrosion current density $-\mu \mathrm{A} / \mathrm{cm}^{2}$} \\
& $\mathrm{R}$ & SP & SF-R & SF-A \\
\hline 7 & 0.83 & 0.69 & 0.02 & 0.11 \\
60 & 0.79 & 0.23 & 0.09 & 0.12 \\
90 & 1.38 & 0.51 & 0.08 & 0.07 \\
120 & 1.94 & 0.79 & 0.07 & 0.07 \\
150 & 2.52 & 0.79 & 0.06 & 0.07 \\
180 & 2.96 & 0.87 & 0.08 & 0.19 \\
270 & 4.24 & 1.09 & 0.07 & 0.25 \\
\hline
\end{tabular}

classification, the steel in SF-R was absolutely in passive conditions, whereas, corrosion risk is low to moderate for steel in SF-A concrete, moderate to high for steel in SP concrete, and high in $\mathrm{R}$ concrete. It is worth mentioning that, after 150 days of exposure, the steel in SF-R concrete elucidates better performance as compared to steel in SF-A concrete in spite of higher cement content of the latter concrete. This behavior is mainly associated with the formation of larger size and concentration of crystalline calcium hydroxide crystals with distinctive hexagonal-prism morphology in the interfacial transition zone [3]. These crystals are the weakest link in the system causing cracks in the direction perpendicular to the $c$-axis. Such effects explicate lower strength of the transition zone than the bulk cement paste in concrete leading to higher corrosion current.

4.3. Corrosion Current versus Corrosion Potential. Commonly, it is known that the corrosion rate is higher at more negative corrosion potential (Ecorr). However, no pragmatic conclusions can be drawn from Ecorr without great hazard of error. In the deprivation of superficial signs of corrosion of the embedded steel, dependable qualitative assessment using potentials data counts on a convenient foreknowledge

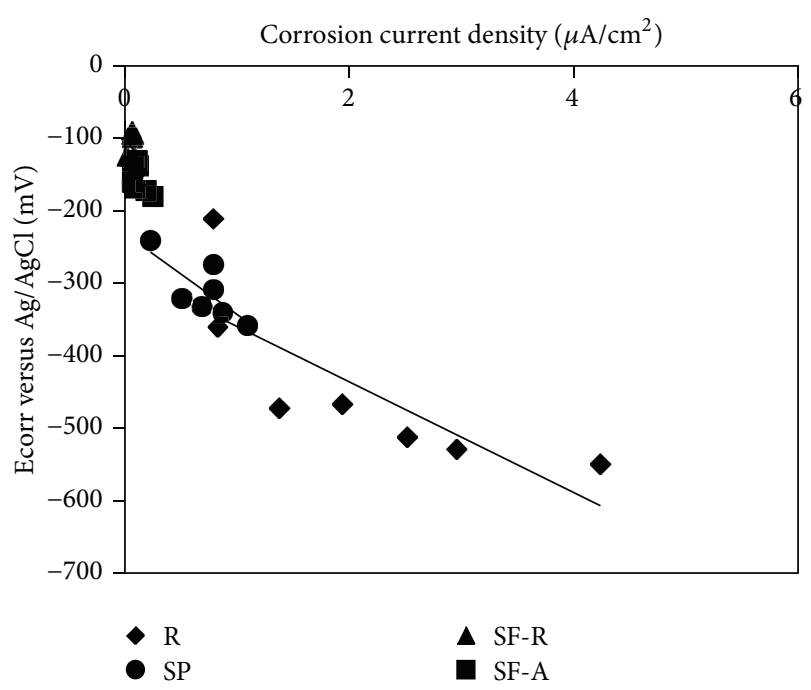

FIGURE 7: Corrosion current density versus Ecorr.

of the electrochemical history of the structure. The corrosion current densities versus Ecorr. plots based on experimental data, Figure 7, indicate different slopes for different types of concrete and were increasing in the following order: R, SP, SF-A, and SF-R. Consequently, weak correlation is observed for steel in a higher corrosion activity system which is steel in $\mathrm{R}$ concrete, and the most obvious trend is associated with steel in lower corrosion activity systems, thus, SF-R specimen. Figure 8 shows the corrosion current density versus corrosion potential data for the whole specimens. Irrespective of the type of concrete, the embedded steel identifies a regular increase in values of Icorr as Ecorr moves toward a more negative value. The points possessed lower corrosion current densities and less negative potentials located in the upper left portion of the curve are related to steel in SF-R concrete, whereas, the points with higher corrosion current densities and more negative potentials are linked with steel in R concrete. The improved corrosion resistance features of steel in high-Strength self-compacting concretes are attributed to the densification of microstructure providing an intensive barrier against the transmission of the intrusive agents. Moreover, the excellent flowability and high resistance to segregation authorized well distribution of cementitious particles, hence produce a consistent and dense microstructure by well intermeshing of the hydration products and provided improved adhesion to steel reinforcement. Similar linear relationships, of negative slope, between Icorr and Ecorr has been reported by Page and Havdahl [33] for steel in various microsilica content cement pastes admixed with chloride and Lambert et al. [34] for steel in conventional concrete exposed to chloride ingress.

It is meritorious to point out that there is no general correlation between the corrosion rates and HCPs [2] since those variables respond distinctly to the specific related parameters essentially, moisture, presence of oxygen, concrete resistance and temperature [35]. From Figures 7 and 8 it can be seen that, for steel in SF-R concrete the values of Ecorr were in the range 


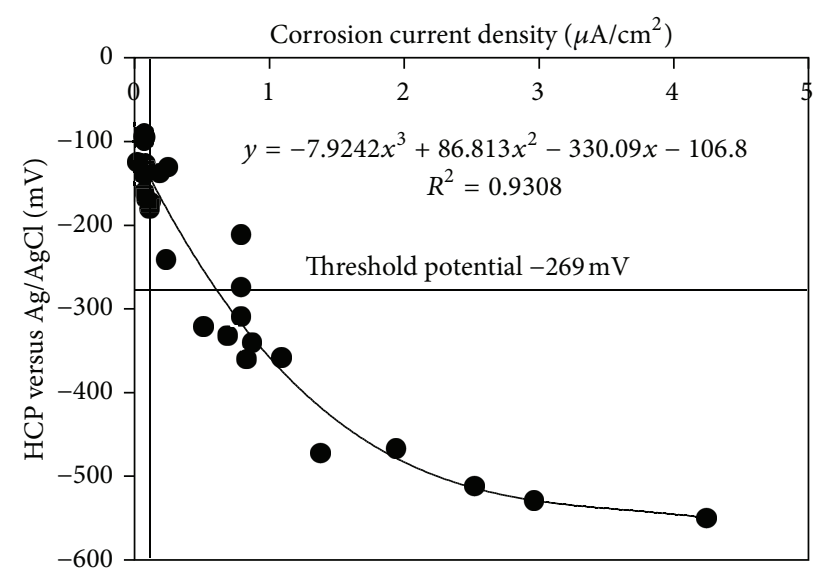

FIGURE 8: Corrosion current density versus HCP.

of $-190 \mathrm{mV} \mathrm{Ag} / \mathrm{AgCl}$, measured at early ages and approached to $-90 \mathrm{mV} \mathrm{Ag} / \mathrm{AgCl}$ at the end of the testing period, and the corresponding values of corrosion current densities were 0.02 and $0.08 \mu \mathrm{A} / \mathrm{cm}^{2}$. This condition clearly indicates passivity of steel in SF-R specimens under $\mathrm{NaCl}$ solution. On the other hand, for steel in $\mathrm{R}$ specimens, the values of Ecorr fall in between -211 to $-550 \mathrm{mV} \mathrm{Ag} / \mathrm{AgCl}$ and the corresponding values of corrosion current densities were between 0.79$4.24 \mu \mathrm{A} / \mathrm{cm}^{2}$. These values reveal the high probability of destruction of the passive protective layer on the surface of steel reinforcement and hence high corrosion activity in most of these specimens at the time of the measurements. Figure 8 plotted for the whole series confirms the correlation between HCPs and corrosion rate for SF-R specimens which all located fully in the passive zone to the left of vertical line representing active corrosion threshold value $\left(0.1 \mu \mathrm{A} / \mathrm{cm}^{2}\right)$ and above the horizontal line (threshold potential, $-269 \mathrm{mV}$ versus $\mathrm{Ag} / \mathrm{AgCl}$ ). Accordingly, it is probable that the effect of microsilica in lowering the $\mathrm{pH}$ values and hydroxide ion concentration of the pore solution phase were being greatly offset by densification of the microstructure of the hydrated cement matrix and excellent intermeshing of the hydration products which tended to stabilize the passivity of steel reinforcement. Moreover, the correlation can be well applied to SF-R, and SFA specimens. The relationship between the corrosion rate and HCPs, Figure 8, indicate active corrosion conditions for steel in R, SP and SF-A concretes located in the active zone to the right of the vertical line $\left(0.1 \mu \mathrm{A} / \mathrm{cm}^{2}\right)$. However, for the some cases the corresponding potentials are less negative than $-269 \mathrm{mV} \mathrm{Ag} / \mathrm{AgCl}$. Consequently, HCP measurements need to be supported by other techniques because wide variations in corrosion rate are linked with a narrow range of potentials that are nobler than $-269 \mathrm{mV} \mathrm{Ag} / \mathrm{AgCl}$.

4.4. Electrical Resistance. The DC electrical resistance for various types of concretes after 60 and 90 days of exposure to chloride solution are presented in Figures 9 and 10, respectively. These values were determined from currentvoltage plots, and a typical plot is shown in Figure 11. Each data point represents the average of three specimens.

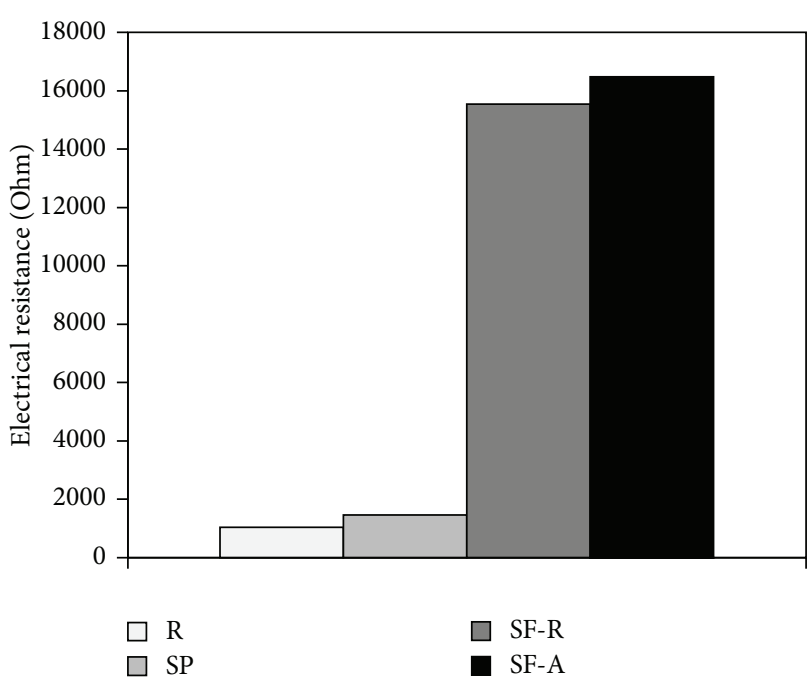

FIGURE 9: Electrical resistance at 60 days.

Results indicated that all types of concrete exhibited an almost continuous increase in electrical resistance with time of exposure. The observed trend may be attributed to the fact that the conduction and electrical current in moist concrete are essentially electrolytic in nature. Therefore, the electrical resistance of concrete will be mainly controlled by the types and concentration of ions of evaporable water in the capillary pores of the cement paste. Since the volume of evaporable water is reduced as hydration proceeds, the electrical resistance is expected to increase with time of exposure. However, the rate of resistance development is more pronounced in SF-R and SF-A concretes as compared to $\mathrm{R}$ and SP concretes. The average rates of resistance development over one month of exposure to chloride solution are $345,340,1443$, and $1471 \Omega$ /day for R, SP, SF-R, and SF-A concrete, respectively. The differences in the age dependency of various types of concrete may be attributed to differences in the hydration process and the subsequent nature and rate of change in the pore system with time of exposure. This process directly influences resistance controlling factors such as the microstructural features of hydrated cement paste in concrete, nature of the transition zone, total pore water content, its composition, and the pore size distribution.

SF-R and SF-A concretes showed significant improvement in resistance as compared to their R, and SP concretes. After 90 days of exposure, the electrical resistance of SF$\mathrm{R}$ is 5.2-fold and 5.1-fold greater than that of $\mathrm{R}$ and SP concretes, respectively. The corresponding values for SF-A concrete are 5.3-fold and 5.2-fold greater. The significant increases in the resistances of SF-R and SF-A concretes are mainly related to the very low $\mathrm{w} / \mathrm{cm}$ ratio and extremely fine pore structures generated through the pore size and grain size refinement processes, hence maintaining a high level of internal integrity, which minimizes the ingress of aggressive ions into those concretes leading to a reduced conductivity and increased electrical resistance. The results are consistent with the Safiuddin et al. findings [10] on the electrical resistivity of self-consolidating concrete. They found that this 


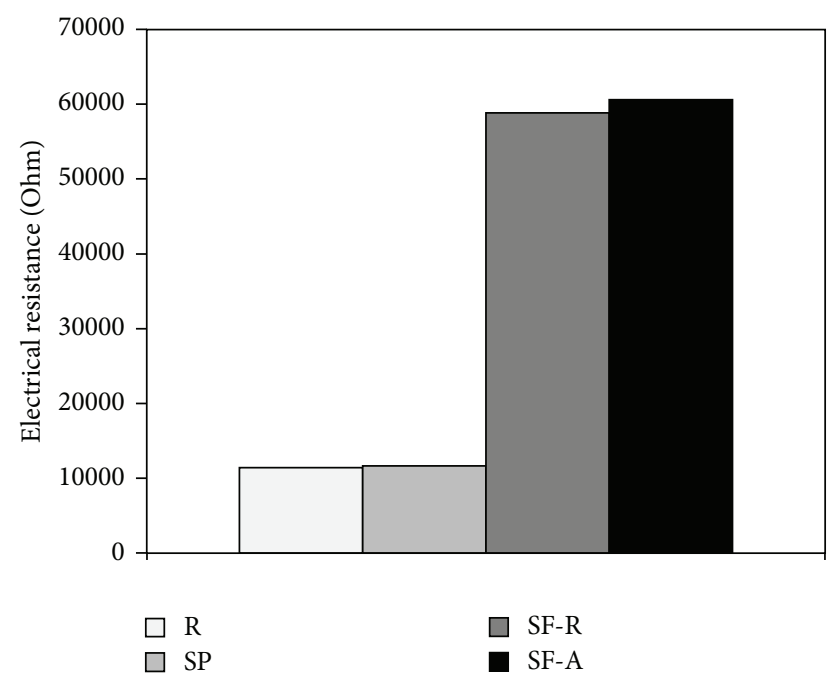

FIGURE 10: Electrical resistance at 90 days.

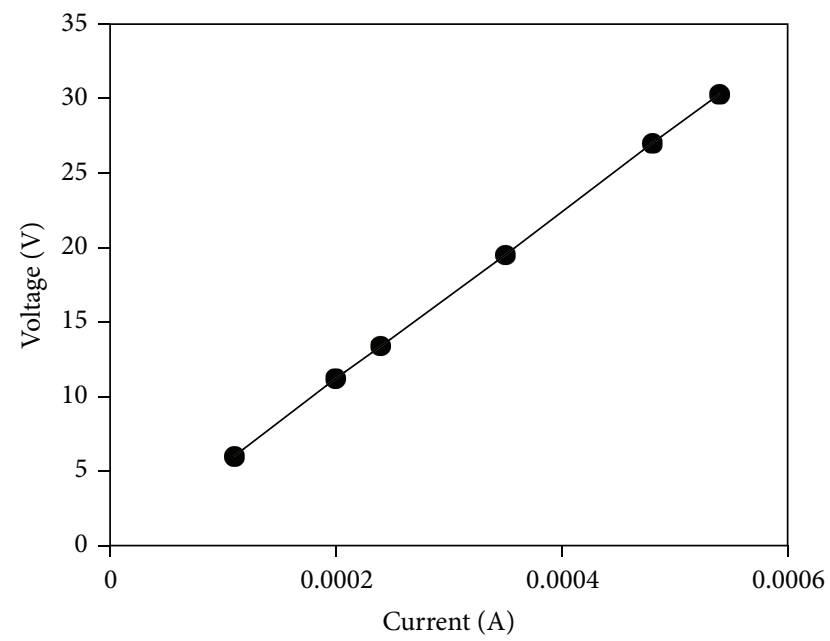

FIgURE 11: Typical V-I plot for SF-R concrete.

concrete gives considerably much higher electrical resistance compared to reference concrete.

4.5. Compressive Strength of Concrete. SF-R concrete containing $10 \%$ silica fume as a partial replacement by weight of cement showed a compressive strength of $96 \mathrm{MPa}$ and $104 \mathrm{MPa}$ at 28 and 270 days of exposure, respectively, whereas the corresponding values for SF-A concrete incorporated $10 \%$ $\mathrm{SF}$ as an addition were $93 \mathrm{MPa}$ and $100 \mathrm{MPa}$. The variation of strength with time is shown in Figure 12. Conventional self-compacting concrete compromised high performance superplasticizer (SP) exhibited a considerable increase in compressive strength at all ages compared to the corresponding reference concretes, Figure 12. The strength at 28 days was $83.5 \mathrm{MPa}$ compared to $45.8 \mathrm{MPa}$ for reference concrete. This behavior is mainly due to a self-compacting feature and significant water reduction caused by SP in concrete leading to the reduction in capillary porosity system. The SP

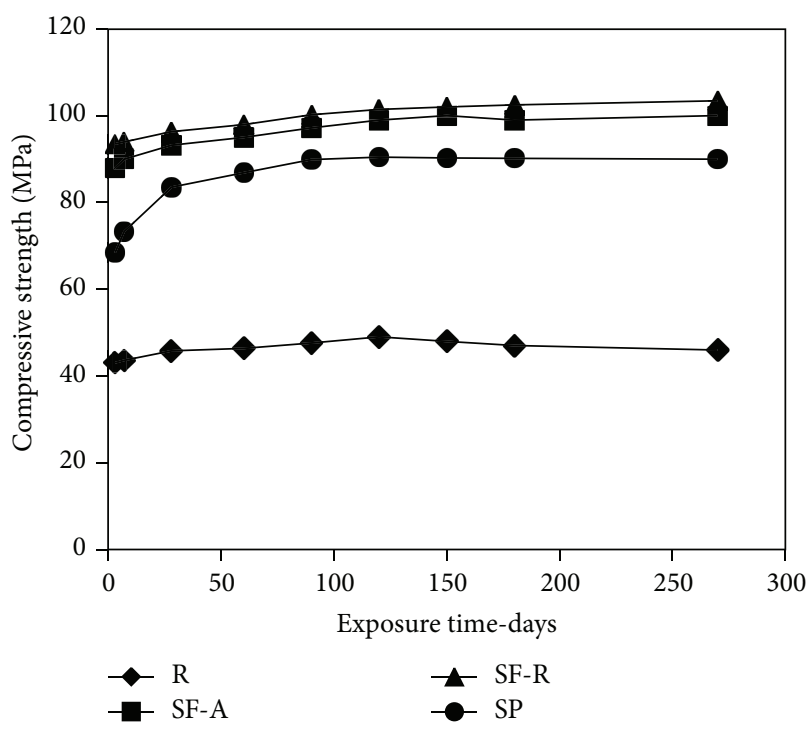

FIgURE 12: Compressive strength of concretes.

surfactants are adsorbed on the surface of cement particles and impart a strong negative charge which tends to disperse the cement agglomerates into individual particles. Therefore, with continuous hydration there is a greater statistical opportunity of intermeshing the products of hydration with fine and coarse aggregate to produce a system of highest integrity and hence of higher strength [36]. In addition, the high repulsing effect caused by SP surfactants can deflocculate the watery ettringite shell around the cement particles, and the small ettringite needles are freed from their watery shell by the adsorption of the SP molecules [37] thus providing a more consistent structure of hydrated cement paste.

Figure 12 shows that SF-R and SF-A have superior performance to SP concrete. This is mainly due to the fact that with a highly active silica fume, the pozzolanic reaction may start as soon as $\mathrm{Ca}(\mathrm{OH})_{2}$ are available from the hydration of Portland cement compounds and thereby strengthen the concrete through the pore size and grain size refinement processes. In the first process, the large capillary voids are filled with a microporous low density calcium silicate hydrates, formed as a secondary hydration product during the pozzolanic reaction. In the second process, nucleation of calcium hydroxide around the fine and well distributed particles of pozzolan will have the effect of replacing the larger and oriented crystals of calcium hydroxide with numerous, small, and fewer oriented crystals plus poorly crystalline reaction products [3]. Mehta and Monteiro suggested that both processes strengthen the cement paste and transition zone thus reducing the microcracking and permeability of concrete [3].

SF-A concrete showed slightly lower strength than SF-R concrete, mainly associated with larger size and concentration of $\mathrm{Ca}(\mathrm{OH})_{2}$ crystals liberated during the hydration of cement in concrete of higher cement content. These crystals offer the feeblest link in the system causing cracks in the direction perpendicular to the $c$-axis. Such effects account for 
lower strength of the transition zone than the bulk cement paste in concrete leading to lower compressive strength. However, the strength is relatively much higher compared to SP concrete Figure 12.

\section{Conclusions}

The following conclusion can be made from the data developed in the present study.

(i) The half-cell potentials (HCPs) of steel in SF-R concrete were considerably nobler than $-269 \mathrm{mV} \mathrm{Ag/}$ $\mathrm{AgCl}$ indicating a state of passive potential. The inclusion of $10 \%$ SF by weight of cement as an addition to the mix in SF-A concrete changed the HCPs of steel to more negative potentials compared to steel in SF-R concrete throughout the testing period. In $\mathrm{R}$ concrete the HCPs of steel drops suddenly to more negative than $-269 \mathrm{mV} \mathrm{Ag/AgCl}$ at 70 days of exposure and the steel in SP concrete exhibited fluctuations in potentials during the testing period.

(ii) The corrosion process of steel in all types of concrete was cathodically controlled. Based on Tafel extrapolation technique, the corrosion currents for steel in SF-R concrete were, respectively, 63- and 16-fold lower than R and SP concretes at the end of the testing period. The corresponding values for steel in SF-A concrete were 17- and 4-fold lower. The superior durability performance of steel in SF$\mathrm{R}$ concrete linked to terrific self-compacting features may significantly expand the service life of structural members and provide vast opportunities for future structural application under severe environmental conditions.

(iii) Corrosion risk classification based on corrosion current densities and HCPs, detected that the steel in SF$\mathrm{R}$ is definitely in the passive condition, while, corrosion risk is low to moderate for steel in SF-A, moderate to high for steel in SP concrete and high for steel in $\mathrm{R}$ concrete. Moreover, large distinctions in corrosion rate are associated with a narrow range of potentials that are less negative than $-269 \mathrm{mV} \mathrm{Ag/AgCl}$. This clearly indicates that HCP measurements may yield deceptive results if considered separately thus, should be always boosted by other techniques. Corrosion current density-Ecorr. plots indicated different slopes for different types of concrete and were increasing in the following order: R, SP, SF-A, and SF-R concrete.

(iv) SF-R and SF-A concretes elucidate significant increase in electrical resistance and compressive strength compared to R and SP concretes. The average rates of resistance development over one month of exposure were $345,340,1443$, and $1471 \Omega$ /day for R, SP, SF-R, and SFA concrete, respectively. The compressive strength of SF-R concretes was $104 \mathrm{MPa}$ at 270 days of exposure, whereas the corresponding value for SF-A concrete was $100 \mathrm{MPa}$. Conventional self-compacting concrete
(SP) exhibited compressive strength of $83.5 \mathrm{MPa}$ compared to $45.8 \mathrm{MPa}$ for $\mathrm{R}$ concrete.

\section{Conflict of Interests}

The authors declare that there is no conflict of interests regarding the publication of this paper.

\section{Acknowledgments}

The authors would like to express deep thanks and appreciation to the Royal Scientific Society as well as the Institute of International Education Scholar Rescue Fund for providing the needed support to conduct this research work.

\section{References}

[1] M. Raupach and P. Schiesbl, "Macrocell sensor systems for monitoring of the corrosion risk of the reinforcement in concrete structures," NDT \& E International, vol. 34, no. 6, pp. 435-442, 2001.

[2] J. P. Broomfield, Corrosion of Steel in Concrete: Understanding, Investigation and Repair, Taylor \& Francis, London, UK, 2nd edition, 2007.

[3] P. K. Mehta and P. J. Monteiro, Concrete: Microstructure, Properties, and Materials, McGraw-Hill, New York, NY, USA, 3rd edition, 2006.

[4] K. H. Khayat, "Workability, testing, and performance of selfconsolidating concrete," ACI Materials Journal, vol. 96, no. 3, pp. 346-353, 1999.

[5] ACI Committee 222, "Corrosion of metals in concrete," ACI Manual of Concrete Practice, Part 1, American Concrete Institute, Farmington Hills, Mich, USA, 2000.

[6] W. Zhu and P. J. M. Bartos, "Permeation properties of selfcompacting concrete," Cement and Concrete Research, vol. 33, no. 6, pp. 921-926, 2003.

[7] T. A. Saylev and R. Francois, "Quality of steel-concrete interface and corrosion of reinforcing steel," Cement and Concrete Research, vol. 33, no. 9, pp. 1407-1415, 2003.

[8] S. Assie, G. Escadeillas, and V. Waller, "Estimates of selfcompacting concrete "potential" durability," Construction and Building Materials, vol. 21, no. 10, pp. 1909-1917, 2007.

[9] H. Yazici, "The effect of silica fume and high-volume class C fly ash on mechanical properties, chloride penetration and freezethaw resistance of self-compacting concrete," Construction and Building Materials, vol. 22, no. 4, pp. 456-462, 2008.

[10] M. Safiuddin, J. S. West, and K.A. Soudki, "Durability performance of self-consolidating concrete," Journal of Applied Sciences Research, vol. 4, no. 12, pp. 1834-1840, 2008.

[11] M. A. Safan, "Performance of beams made of low-cost selfcompacting concrete in an aggressive environment," Acta Polytechnica, vol. 51, no. 5, pp. 120-130, 2011.

[12] H. F. Dehwah, "Corrosion resistance of self-compacting concrete incorporated quarry dust powder, silica fume and fly ash," Construction and Building Materials, vol. 37, pp. 277-282, 2012.

[13] M. Uysal, K. Yilmaz, and M. Ipek, "The effect of mineral admixtures on mechanical properties, chloride ion permeability and impermeability of self-compacting concrete," Construction and Building Materials, vol. 27, no. 1, pp. 263-270, 2012. 
[14] A. Hassan, M. Hossain, and M. Lachemi, "Corrosion resistance of self-consolidating concrete in full-scale reinforced beams," Cement and Concrete Composites, vol. 31, no. 1, pp. 29-38, 2009.

[15] H. Yu, X. Shi, W. H. Hartt, and B. Lu, "Laboratory investigation of reinforcement corrosion initiation and chloride threshold content for self-compacting concrete," Cement and Concrete Research, vol. 40, no. 10, pp. 1507-1516, 2010.

[16] American Society for Testing and Materials, ASTM C150: Standard Specification for Portland Cement, ASTM, Philadelphia, Pa, USA, 2002.

[17] American Society for Testing and Materials, ASTM C1240: Standard Specification for Silica Fume Used in Cementitious Mixtures, ASTM, Philadelphia, Pa, USA, 2005.

[18] American Society for Testing and Materials, ASTM C494: Standard Specification for Chemical Admixture for Concrete, ASTM, Philadelphia, Pa, USA, 2001.

[19] American Society for Testing and Materials, ASTM C33: Standard Specification for Concrete Aggregate, ASTM, Philadelphia, $\mathrm{Pa}, \mathrm{USA}, 2003$.

[20] The European Guidelines for Self Compacting Concrete, Specification, Production and Use, 2005.

[21] American Society for Testing and Materials, ASTM C143: Standard Test Method for Slump of Hydraulic Cement Concrete, ASTM, Philadelphia, Pa, USA, 2000.

[22] American Society for Testing and Materials, ASTM C1611: Standard Test Method for Slump Flow of Self-Consolidating Concrete, ASTM, Philadelphia, Pa, USA, 2005.

[23] American Society for Testing and Materials, ASTM C1621: Standard Test Method for Passing Ability of Self-Consolidating Concrete by J-Ring, ASTM, Philadelphia, Pa, USA, 2009.

[24] EFNARC, "Specification and guidelines for self-compacting concrete," European Federation Dedicated to Specialist Construction Chemicals and Concrete Systems, 2002.

[25] American Society for Testing and Materials, ASTM C39/C39M: Standard Test Method for Compressive Strength of Cylindrical Concrete Specimens, ASTM, Philadelphia, Pa, USA, 2001.

[26] American Society for Testing and Materials, ASTM C876: Standard Test Method for Half-Cell Potentials of Uncoated Reinforcing Steel in Concrete, ASTM, Philadelphia, Pa, USA, 1999.

[27] P. Rodriguez, E. Ramirez, and J. A. Gonzalez, "Methods for studying corrosion in reinforced concrete," Magazine of Concrete Research, vol. 46, no. 167, pp. 81-90, 1994.

[28] C. Andrade, J. Gulikers, R. Polder, and M. Raupach, "Halfcell potential measurements-potential mapping on reinforced concrete structures," Materials and Structures, vol. 36, pp. 461471, 2003.

[29] C. Andrade and C. Alonso, "Corrosion rate monitoring in the laboratory and on-site," Construction and Building Materials, vol. 10, no. 5, pp. 315-328, 1996.

[30] M. Stern and A. Geary, "Electrochemical polarizationtheoretical analysis of the shape of polarization curves," Journal of the Electrochemical Society, vol. 104, no. 1, pp. 56-63, 1957.

[31] H. Arup, Corrosion of Reinforcement in Concrete Construction, Society of Chemical Industry, London, UK, 1983.

[32] R. D. Browne, M. P. Geoghegan, and A. F. Baker, "Analysis of structural condition from durability results," in Corrosion of Reinforcement in Concrete Construction, A. P. Crane, Ed., Ellis Horwood, London, UK, 1983.

[33] C. L. Page and J. Havdahl, "Electrochemical monitoring of corrosion of steel in microsilica cement pastes," Materials and Structures, vol. 18, no. 1, pp. 41-47, 1985.
[34] P. Lambert, C. L. Page, and P. R. W. Vassie, "Investigations of reinforcement corrosion. 2. Electrochemical monitoring of steel in chloride-contaminated concrete," Materials and Structures, vol. 24, no. 5, pp. 351-358, 1991.

[35] J. A. Grubb, J. Blunt, C. P. Ostertag, and T. M. Devine, "Effect of steel microfibers on corrosion of steel reinforcing bars," Cement and Concrete Research, vol. 37, no. 7, pp. 1115-1126, 2007.

[36] M. R. Rixom, Concrete Admixtures: Use and Applications, Construction Press, Lancaster, UK, 1977.

[37] P. C. Kreiger, "Plasticizers and dispersing admixtures," in Proceedings of the Concrete International Admixtures (CI '80), pp. 1-17, London, UK, 1980. 

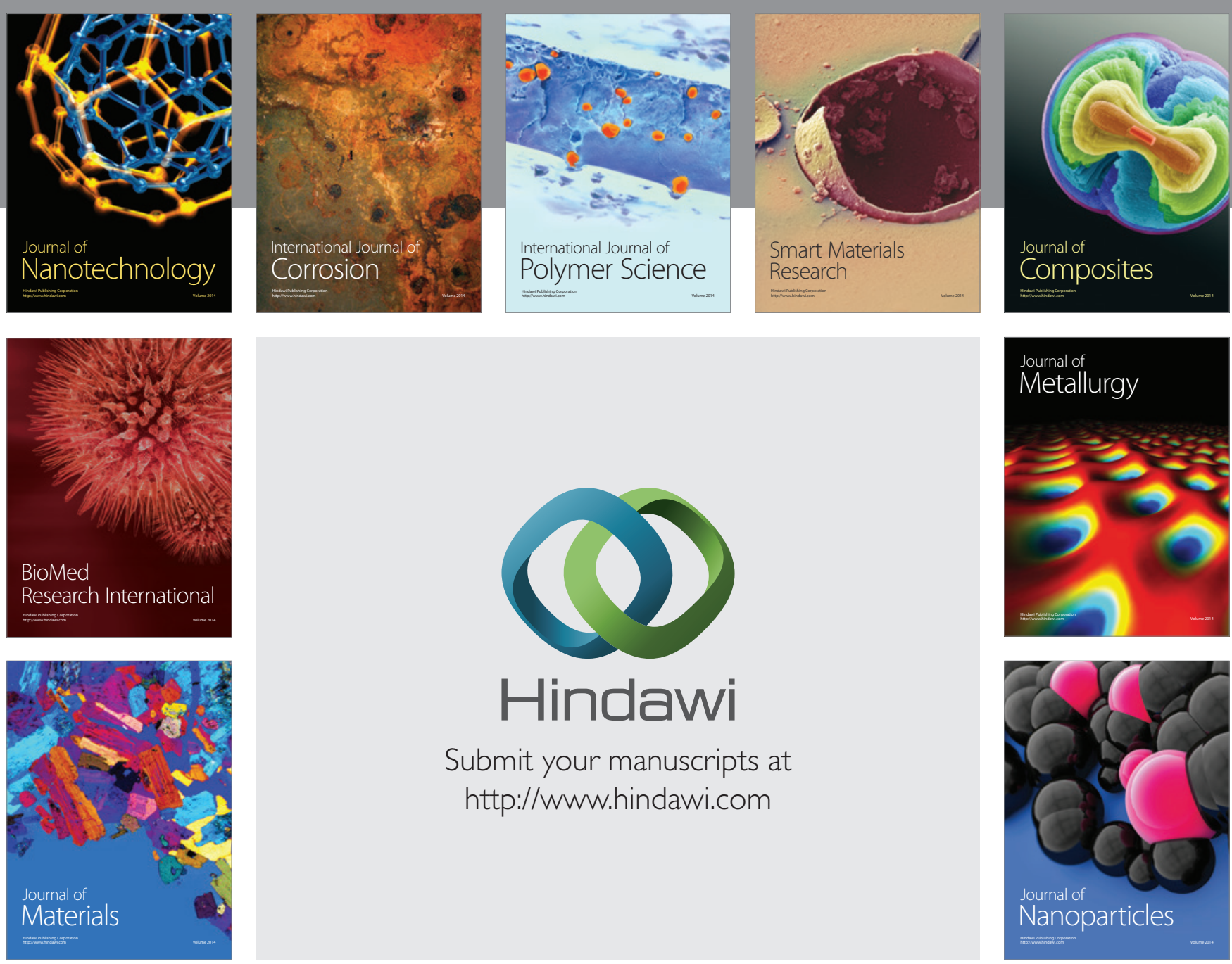

Submit your manuscripts at http://www.hindawi.com
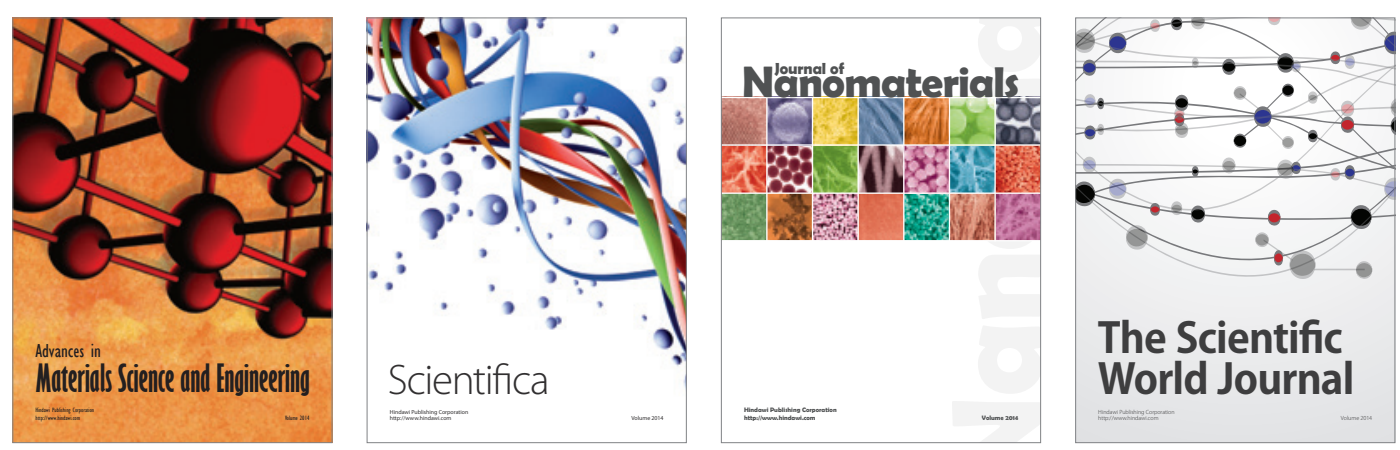

\section{The Scientific World Journal}
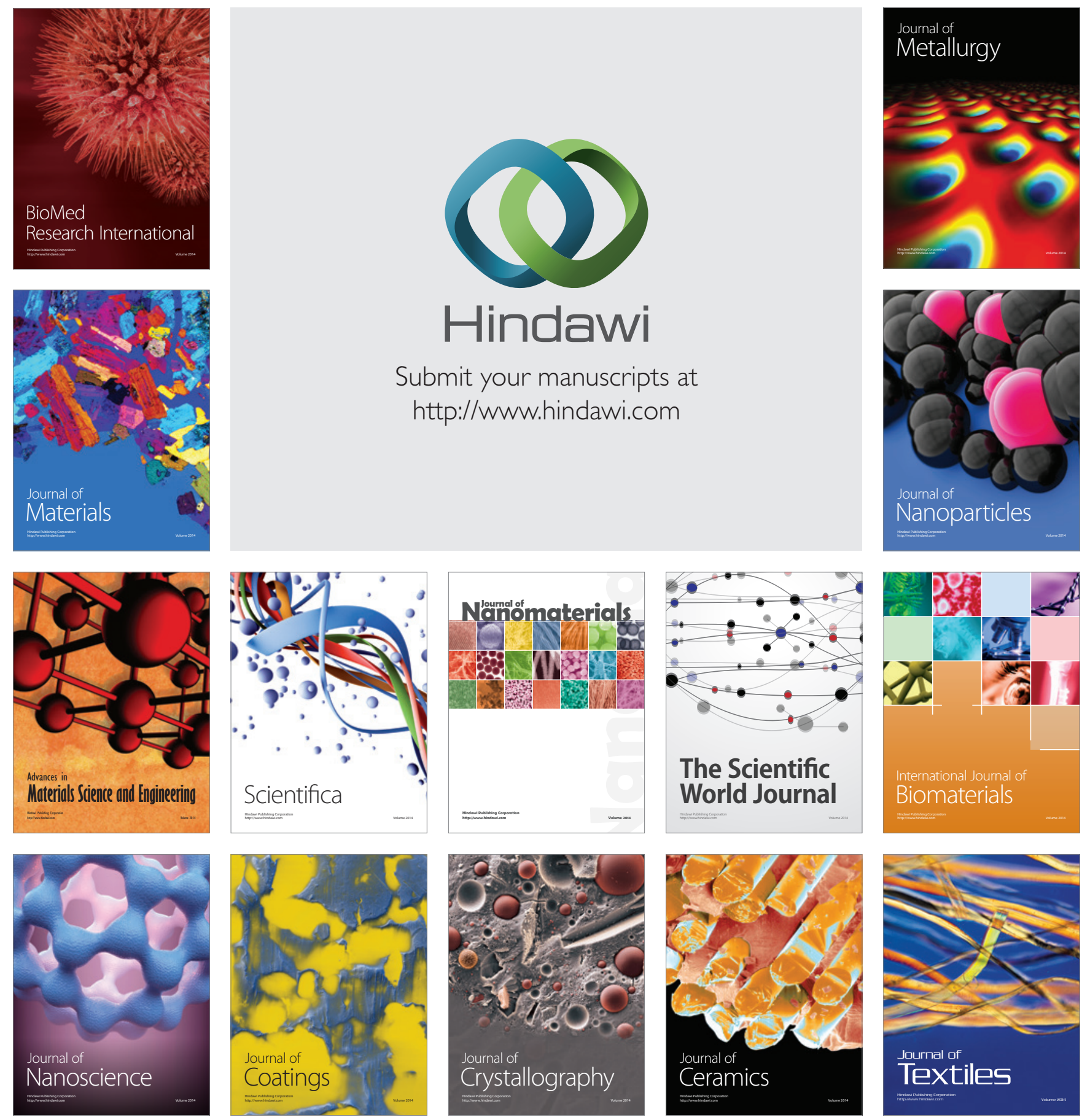